\title{
Recombinant Inbred Line Differential Identifies Race-Specific Resistance to Phytophthora Root Rot in Capsicum annuum
}

\author{
O. Sy, R. Steiner, and P. W. Bosland
}

First and third authors: Department of Plant and Environmental Sciences; and second author: University Statistics Center, New Mexico State University, Las Cruces, NM 88003.

Accepted for publication 26 March 2008.

\section{ABSTRACT}

Sy, O., Steiner, R., and Bosland, P. W. 2008. Recombinant inbred line differential identifies race-specific resistance to Phytophthora root rot in Capsicum аппиит. Phytopathology 98:867-870.

A differential series is the normal method for identification of races within a plant pathogen and a host interaction. A host differential is extremely useful for phytopathological as well as breeding purposes. A set of recombinant inbred lines (RILs) were developed and characterized for race differentiation of Phytophthora root rot caused by Phytophthora capsici. The highly resistant Capsicum annuum accession Criollo de
Morelos-334 was hybridized to a susceptible cultivar, Early Jalapeno, to generate the RIL population. The host differential characterized 17 isolates of $P$. capsici into 13 races. The establishment of a stable host differential for the $P$. capsici and $C$. апnиum interaction will assist researchers in understanding the complex inheritance of resistance to Phytophthora root rot and to develop resistant cultivars.

Additional keywords: chile pepper, single seed descent, host-pathogen interaction.
The oomycete Phytophthora capsici Leon. is the causative agent of Phytophthora root rot, stem blight, foliar blight, and fruit rot in chile pepper (Capsicum annuum L.) $(16,20)$. P. capsici is responsible for devastating losses worldwide (13). Currently, no truly resistant cultivar is available to aid in chile production. Nevertheless, sources of resistance have been identified. Among these, the C. annuum accession Criollo de Morelos-334 (CM-334) has the highest level of resistance against all known isolates of $P$. capsici (11).

Breeding for Phytophthora-resistant chile pepper is difficult and complex, especially with the existence of physiological races (11). Oelke et al. (11) identified nine races for Phytophthora root rot and four races for Phytophthora foliar blight in chile pepper based on a differential reaction of selected $C$. annuum cultivars. This study was one of the very first attempts to characterize races of $P$. capsici.

Within P. capsici, both A1 and A2 mating types exist, and have been found in the same field in New Mexico (8). This increases the probability of sexual recombination leading to the emergence of new races. To assist with the understanding of the inheritance of resistance in chile pepper to $P$. capsici, an efficient and established system to identify races would be beneficial.

A set of host differentials is comprised of lines or cultivars of a host that have one or more resistance genes to a pathogen. Using a set of recombinant inbred lines (RILs) to achieve this goal has the advantages of combining the maximum genetic variability within the population (equal representation of genotypes) with homozygous genotypes that can be replicated permanently without risk of segregation.

The Phytophthora infestans ([Mont.] de Bary) and potato (Solanum tuberosum L.) system represents a successful example of host differentials generated from a highly resistant accession Solanum demissum Lindl. The "Black's differentials" developed

Corresponding author: P. W. Bosland; E-mail address: pbosland@ nmsu.edu

doi:10.1094/PHYTO-98-8-0867

(c) 2008 The American Phytopathological Society in 1953 are still being used successfully to characterize new races of $P$. infestans $(3,7)$. Other examples where race-specific resistance has been characterized using RILs exist in soybean (Glycine $\max$ [L.] Merr.), sunflower (Helianthus annuus L.), and chickpea (Cicer arietinum L.) $(1,17,18,21)$. The objective of this study was to develop a set of RILs that could be used as a host differential to characterize race differentiation of $P$. capsici causing root rot on chile pepper.

\section{MATERIALS AND METHODS}

Plant materials. From hybridization between the resistant accession Criollo de Morelos-334 (CM-334) and the susceptible cultivar, Early Jalapeno, a set of recombinant inbred lines (RILs) was developed. The accession, CM-334 is a landrace from Mexico that has the broadest level of resistance found in any $C$. annuum accession. In fact, there is not a known isolate of $P$. capsici that causes root rot on it. The single seed descent procedure was used to obtain the RILs (4). The $F_{1}$ generation was selfed to generate an $\mathrm{F}_{2}$ population, and for each subsequent generation a single seed was harvested from a single self-pollinated plant and sown. This process was repeated until the $\mathrm{F}_{7}$ generation with the development of 76 New Mexico RILs (NMRILs). This study randomly selected 26 NMRILs out of the 76 NMRILS for disease screening. The accession, CM-334, served as the resistant control, whereas a highly susceptible $C$. annuum accession NMCA 10399 served as the susceptible control.

Seedlings were grown in planting trays composed of 72 cells divided into 18 four-celled containers (TOD 1804, T.O. Plastics, Clearwater, MN). Cells were filled with a commercially prepared peat moss-vermiculite soil mixture (Sun Gro Redi-earth plug and seedling mix, Sun Gro Horticulture, WA). Seeds were sown and after germination, each cell was thinned to the two healthiest plants.

Isolates and inoculum preparation. A total of 17 isolates (Table 1) collected mostly from New Mexico were used to inoculate the seedlings, following the inoculation procedure of Bosland and Lindsey (2). Each isolate was originally maintained on water 
agar plates for long-term storage in $100 \times 20 \mathrm{~mm}$ polystyrene petri dishes. To prepare the inoculum, the water agar was cut into $0.5 \mathrm{~cm}$ diameter plugs and transferred to V8 agar medium (14). The V8 plates were then placed in an incubator at $28^{\circ} \mathrm{C}$. After 8 days, the medium was cut into $2 \times 2 \mathrm{~cm}^{2}$ pieces and placed in $150 \times 15 \mathrm{~mm}$ petri plates, partially filled with distilled water. After 3 days, the plates were removed from the incubator, and underwent a temperature-shock to induce the release of zoospores, i.e., plates were put in a refrigerator at $10^{\circ} \mathrm{C}$ for $1 \mathrm{~h}$ and then placed at $24^{\circ} \mathrm{C}$ for at least $30 \mathrm{~min}$. The liquid containing the zoospores was collected and the concentration of live zoospores was determined by counting in a Newbauer chamber under $10 \times$ magnification. The inoculum was diluted to obtain a final zoospore concentration of 2,000 zoospores $/ \mathrm{ml}$.

Root screening and scoring. Each isolate was tested on 72 plants per NMRIL with a total of three replications of eight plants each randomized within a tray, and the experiment was repeated twice. Seedlings were inoculated at the four- to six-true-leaf stage as described by Bosland and Lindsey (2). The planting trays were placed into water to saturate the root zone. Each plant cell received $5 \mathrm{ml}$ of the prepared inoculum, giving a final concentration of 10,000 zoospores per plant cell. The water-saturated root zone condition was maintained for $48 \mathrm{~h}$ before the plant trays were removed, allowed to drain, and placed on a greenhouse bench. Propagation pads on the greenhouse benches ensured a constant soil temperature of $28^{\circ} \mathrm{C}$ was maintained.

Approximately 10 days after inoculation, when the susceptible check exhibited extreme root rot symptoms, plants were scored for resistance or susceptibility. Plants with no lesions in the root area were considered resistant, whereas plants with symptoms ranging from very small lesions to death were considered suscep-

TABLE 1. Origin of isolates of Phytophthora capsici isolated from Capsicum аппиит

\begin{tabular}{lcl}
\hline Isolates & Acquisition date & Origin \\
\hline PWB 24 & 1988 & New Mexico \\
PWB 66 & 2000 & New Mexico \\
PWB 80 & 2000 & Netherlands \\
PWB 83 & 2003 & New Mexico \\
PWB 84 & 1988 & New Mexico \\
PWB 85 & 2004 & New Mexico \\
PWB 86 & 1988 & New Mexico \\
PWB 87 & 1988 & New Mexico \\
PWB 90 & 1988 & New Mexico \\
PWB 91 & 1988 & New Mexico \\
PWB 94 & 2004 & New Mexico \\
PWB 96 & 1992 & New Mexico \\
PWB 97 & 1992 & New Mexico \\
PWB 98 & 1992 & New Mexico \\
PWB 99 & 2002 & New Mexico \\
PWB 101 & 2003 & New Mexico \\
PWB 103 & 2003 & California \\
\hline
\end{tabular}

tible (Fig. 1). Once a plant begins to show even a small lesion, it will eventually die.

Experimental design. Each four-celled pack represented one NMRIL, and within a tray each NMRIL was replicated three times and randomly distributed in the tray. Randomly placed in each tray was a four-celled pack each of the resistant check, CM334, and the susceptible check, NMCA 10399. All experiments were repeated twice.

Statistical design. The data were analyzed using SAS system (14). To decide whether or not the data could be pooled, a chisquare $\left(\chi^{2}\right)$ test of homogeneity was performed over the three repetitions. The data were pooled if the $\chi^{2}$ test was significant $(P>0.05)$. To determine if an NMRIL was resistant or susceptible, a chi-square $\left(\chi^{2}\right)$ test of homogeneity was performed testing each to the resistant control (CM-334) and the susceptible control (NMCA 10399). The NMRILs were considered resistant or susceptible if the $\chi^{2}$ test was significant $(P>0.05)$ for a specific comparison.

Mating type determination. All isolates were individually paired with a known A1 and A2 isolate to determine mating types. The isolates were placed $3 \mathrm{~cm}$ apart on clarified V8 media. Plates were incubated at $25^{\circ} \mathrm{C}$ for 3 to 5 days and then checked for oospore formation.

\section{RESULTS}

From the 17 isolates studied, 16 were virulent on the susceptible control NMCA 10399, only PWB 84 was unable to cause disease on NMCA 10399. Three isolates (PWB 83, 87, and 96) were unable to infect any of the NMRILs, but did cause root rot symptoms on NMCA 10399 (data not shown). The resistant control, CM-334, did not show any root rot symptoms when challenged by any of the 17 isolates.

The 13 isolates that caused disease symptoms on the NMRILs showed different levels of virulence. For instance, isolates PWB 80 and PWB 99 were the most virulent, as they caused disease on more NMRILs than any other isolates, 19 and 20, respectively. On the other hand, isolate PWB 101 was the least virulent as it caused disease on only 5 NMRILs, less than any other isolate (Table 2). Congruously, NMRIL C, NMRIL F, NMRIL J, NMRIL $\mathrm{P}$, and NMRIL $\mathrm{Q}$ were the most resistant, whereas NMRIL D, $\mathrm{AA}, \mathrm{AB}$, and $\mathrm{AC}$ were the least resistant (Table 2). From the 26 NMRILs that were challenged with the Phytophthora isolates, eight were sufficient to show a differential reaction as a host differential (Table 3).

\section{DISCUSSION}

We report here the development of a unique set of host differentials for the characterization of races of $P$. capsici causing Phytophthora root rot in chile pepper. This host differential was

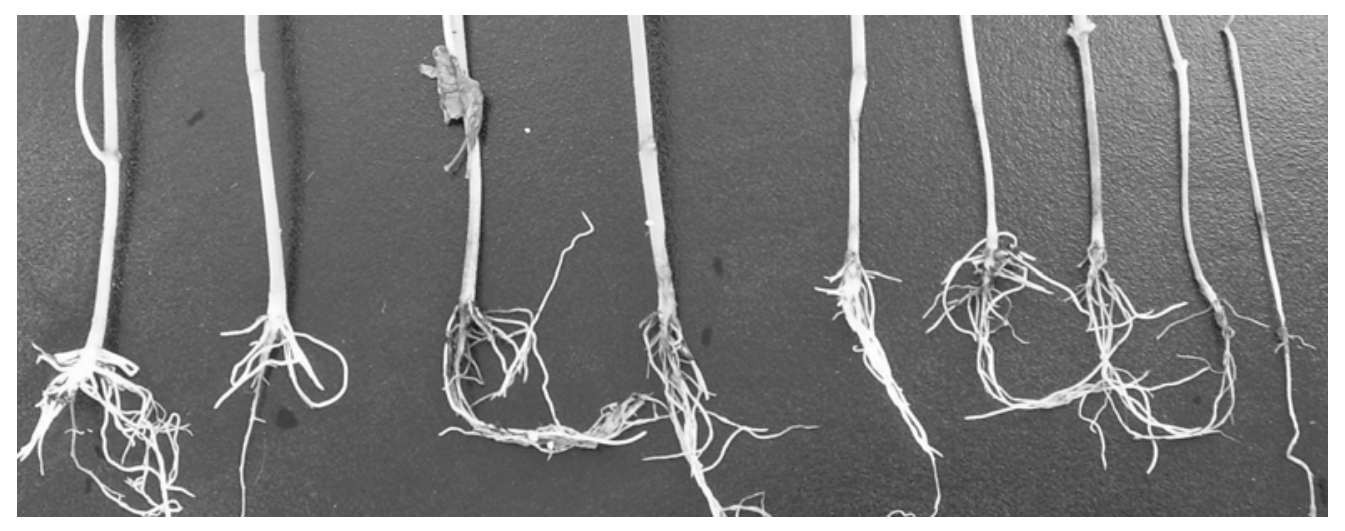

Fig. 1. Range of susceptible Phytophthora root rot symptoms. 
based on recombinant inbred lines (RILs) that were established by hybridizing the resistant accession 'Criollo de Morelos-334' to the susceptible jalapeno cultivar, Early Jalapeno. From an initial pool of 26 RILs, eight were selected as the New Mexico RILs (NMRILs), which enabled field isolates of $P$. capsici to be assigned to 13 races. The successful development of the NMRILs provides a valuable tool for researchers to investigate the genetics of the P. capsici-Capsicum annuum interaction in more detail than has previously been possible. $P$. capsici is a heterothallic organism, and mating type analysis found the presence of both A1 and A2 types within the races studied (Table 3 ), confirming previous findings that both A1 and A2 genotypes exist in New Mexico, and even within the same field (8). Thus, the likelihood of new race development through sexual recombination is high. The NMRILs clearly provide a system for characterizing the race of any unknown isolate, through the unique pattern of reactions across the eight differentials. The NMRILs are available, from the Chile Pepper Institute, hotchile@nmsu.edu, to bonafide researchers.

The value of defining pathogen races is clear from other hostpathogen systems, i.e., in soybean (Glycine max [L.] Merr.), sunflower (Helianthus annuus L.), and chickpea (Cicer arietinum L.) $(1,17,18,21)$. Previous attempts to define races in $P$. capsici using cultivars have not been effective $(11,17)$. Thus, the NMRILs will contribute to defining the distribution and type of virulence

TABLE 2. Phenotypic response of the 26 New Mexico recombinant inbred lines (NMRIL) tested to the 13 virulent isolates of Phytophthora capsici

\begin{tabular}{|c|c|c|c|c|c|c|c|c|c|c|c|c|c|}
\hline \multirow[b]{2}{*}{ Accessions } & \multicolumn{13}{|c|}{ PWB isolates } \\
\hline & $99^{\mathrm{a}}$ & 80 & 91 & 103 & 66 & 85 & 86 & 98 & 24 & 97 & 94 & 90 & 101 \\
\hline CM-334b & $\mathrm{R}^{\mathrm{c}}$ & $\mathrm{R}$ & $\mathrm{R}$ & $\mathrm{R}$ & $\mathrm{R}$ & $\mathrm{R}$ & $\mathrm{R}$ & $\mathrm{R}$ & $\mathrm{R}$ & $\mathrm{R}$ & $\mathrm{R}$ & $\mathrm{R}$ & $\mathrm{R}$ \\
\hline NMRIL-F & $\mathrm{R}$ & $\mathrm{R}$ & $\mathrm{R}$ & $\mathrm{R}$ & $\mathrm{R}$ & $\mathrm{R}$ & $\mathrm{R}$ & $\mathrm{R}$ & $\mathrm{R}$ & $\mathrm{R}$ & $\mathrm{R}$ & $\mathrm{R}$ & $\mathrm{R}$ \\
\hline NMRIL-J & $\mathrm{R}$ & $\mathrm{R}$ & $\mathrm{R}$ & $\mathrm{R}$ & $\mathrm{R}$ & $\mathrm{R}$ & $\mathrm{R}$ & $\mathrm{R}$ & $\mathrm{R}$ & $\mathrm{R}$ & $\mathrm{R}$ & $\mathrm{R}$ & $\mathrm{R}$ \\
\hline NMRIL-P & $\mathrm{R}$ & $\mathrm{R}$ & $\mathrm{R}$ & $\mathrm{R}$ & $\mathrm{R}$ & $\mathrm{R}$ & $\mathrm{R}$ & $\mathrm{R}$ & $\mathrm{R}$ & $\mathrm{R}$ & $\mathrm{R}$ & $\mathrm{R}$ & $\mathrm{R}$ \\
\hline NMRIL-Q & $\mathrm{R}$ & $\mathrm{R}$ & $\mathrm{R}$ & $\mathrm{R}$ & $\mathrm{R}$ & $\mathrm{R}$ & $\mathrm{R}$ & $\mathrm{R}$ & $\mathrm{R}$ & $\mathrm{R}$ & $\mathrm{R}$ & $\mathrm{R}$ & $\mathrm{R}$ \\
\hline NMRIL-C & $\mathrm{R}$ & $\mathrm{R}$ & $\mathrm{R}$ & $\mathrm{R}$ & $\mathrm{R}$ & $\mathrm{R}$ & $\mathrm{R}$ & $\mathrm{R}$ & $\mathrm{R}$ & $\mathrm{R}$ & $\mathrm{R}$ & $\mathrm{R}$ & $\mathrm{R}$ \\
\hline NMRIL-H & $\mathrm{S}^{\mathrm{e}}$ & $\mathrm{R}$ & $\mathrm{R}$ & $\mathrm{R}$ & $\mathrm{R}$ & $\mathrm{R}$ & $\mathrm{S}$ & $\mathrm{R}$ & $\mathrm{R}$ & $\mathrm{R}$ & $\mathrm{S}$ & $\mathrm{R}$ & $\mathrm{R}$ \\
\hline NMRIL-Z & $\mathrm{S}$ & $\mathrm{S}$ & $S$ & $\mathrm{R}$ & $\mathrm{S}$ & $\mathrm{S}$ & $\mathrm{R}$ & $\mathrm{R}$ & $\mathrm{R}$ & $\mathrm{R}$ & $\mathrm{R}$ & $\mathrm{R}$ & $\mathrm{R}$ \\
\hline NMRIL-B & $\mathrm{S}$ & $\mathrm{S}$ & $\mathrm{S}$ & $\mathrm{S}$ & $\mathrm{S}$ & $\mathrm{R}$ & $\mathrm{R}$ & $\mathrm{R}$ & $\mathrm{S}$ & $\mathrm{R}$ & $\mathrm{R}$ & $\mathrm{R}$ & $\mathrm{R}$ \\
\hline NMRIL-A & $\mathrm{S}$ & $\mathrm{S}$ & $\mathrm{R}$ & $\mathrm{S}$ & $\mathrm{R}$ & $\mathrm{R}$ & $\mathrm{R}$ & $\mathrm{R}$ & $\mathrm{R}$ & $\mathrm{S}$ & $\mathrm{S}$ & $\mathrm{S}$ & $\mathrm{S}$ \\
\hline NMRIL-K & $\mathrm{R}$ & $\mathrm{S}$ & $\mathrm{S}$ & $\mathrm{S}$ & $\mathrm{R}$ & $\mathrm{R}$ & $\mathrm{S}$ & $\mathrm{S}$ & $\mathrm{R}$ & $\mathrm{S}$ & S & $\mathrm{R}$ & $\mathrm{R}$ \\
\hline NMRIL-O & $\mathrm{S}$ & $\mathrm{S}$ & $\mathrm{S}$ & $\mathrm{S}$ & $\mathrm{R}$ & $\mathrm{R}$ & $\mathrm{S}$ & $\mathrm{S}$ & $\mathrm{S}$ & $\mathrm{R}$ & $\mathrm{R}$ & $\mathrm{R}$ & $\mathrm{R}$ \\
\hline NMRIL-X & $\mathrm{S}$ & $\mathrm{R}$ & $\mathrm{S}$ & $\mathrm{R}$ & $\mathrm{R}$ & $\mathrm{S}$ & $\mathrm{R}$ & $\mathrm{S}$ & $\mathrm{R}$ & $\mathrm{S}$ & $\mathrm{S}$ & $\mathrm{R}$ & $\mathrm{S}$ \\
\hline NMRIL-G & $\mathrm{S}$ & $\mathrm{S}$ & $\mathrm{S}$ & $\mathrm{S}$ & $\mathrm{S}$ & $\mathrm{S}$ & $\mathrm{S}$ & $\mathrm{S}$ & $\mathrm{S}$ & $\mathrm{R}$ & $\mathrm{R}$ & $\mathrm{R}$ & $\mathrm{R}$ \\
\hline NMRIL-L & $\mathrm{S}$ & $\mathrm{S}$ & $\mathrm{S}$ & $\mathrm{S}$ & $\mathrm{S}$ & $\mathrm{S}$ & $\mathrm{S}$ & $\mathrm{R}$ & $\mathrm{S}$ & $\mathrm{R}$ & $\mathrm{S}$ & $\mathrm{R}$ & $\mathrm{R}$ \\
\hline NMRIL-T & $S$ & $\mathrm{~S}$ & $\mathrm{~S}$ & $\mathrm{~S}$ & $\mathrm{~S}$ & $\mathrm{~S}$ & $\mathrm{~S}$ & $\mathrm{~S}$ & $\mathrm{R}$ & $\mathrm{R}$ & $\mathrm{R}$ & $\mathrm{R}$ & $S$ \\
\hline NMRIL-I & $\mathrm{S}$ & $\mathrm{S}$ & $\mathrm{S}$ & $\mathrm{S}$ & $\mathrm{S}$ & $\mathrm{S}$ & $\mathrm{S}$ & $\mathrm{S}$ & $\mathrm{S}$ & $\mathrm{S}$ & $\mathrm{R}$ & $\mathrm{R}$ & $\mathrm{R}$ \\
\hline NMRIL-N & $S$ & $\mathrm{~S}$ & $\mathrm{~S}$ & $\mathrm{~S}$ & $\mathrm{~S}$ & $\mathrm{~S}$ & $\mathrm{~S}$ & $\mathrm{~S}$ & S & $\mathrm{S}$ & $\mathrm{R}$ & $\mathrm{R}$ & $\mathrm{R}$ \\
\hline NMRIL-R & $\mathrm{S}$ & $\mathrm{S}$ & $\mathrm{S}$ & $\mathrm{S}$ & $\mathrm{S}$ & $\mathrm{S}$ & $\mathrm{R}$ & $\mathrm{S}$ & $\mathrm{S}$ & $\mathrm{S}$ & $\mathrm{S}$ & $\mathrm{R}$ & $\mathrm{R}$ \\
\hline NMRIL-S & $\mathrm{S}$ & $\mathrm{S}$ & $\mathrm{S}$ & $\mathrm{S}$ & $\mathrm{S}$ & $\mathrm{S}$ & $\mathrm{S}$ & $\mathrm{S}$ & $\mathrm{S}$ & $\mathrm{S}$ & $\mathrm{R}$ & $\mathrm{R}$ & $\mathrm{R}$ \\
\hline NMRIL-V & $\mathrm{S}$ & $\mathrm{S}$ & $\mathrm{S}$ & $\mathrm{S}$ & $\mathrm{S}$ & $\mathrm{S}$ & $\mathrm{S}$ & $\mathrm{S}$ & $\mathrm{S}$ & $\mathrm{R}$ & $\mathrm{S}$ & $\mathrm{R}$ & $\mathrm{R}$ \\
\hline NMRIL-E & $\mathrm{S}$ & $\mathrm{S}$ & $\mathrm{S}$ & $\mathrm{S}$ & $\mathrm{S}$ & $\mathrm{S}$ & $\mathrm{S}$ & $\mathrm{S}$ & $\mathrm{S}$ & $\mathrm{S}$ & $\mathrm{S}$ & $\mathrm{R}$ & $\mathrm{R}$ \\
\hline NMRIL-M & $\mathrm{S}$ & $\mathrm{S}$ & $\mathrm{S}$ & $\mathrm{S}$ & $\mathrm{S}$ & $\mathrm{S}$ & $\mathrm{S}$ & $\mathrm{S}$ & $\mathrm{S}$ & $\mathrm{R}$ & $\mathrm{S}$ & $\mathrm{S}$ & $\mathrm{R}$ \\
\hline NMRIL-D & $\mathrm{S}$ & $\mathrm{S}$ & $\mathrm{S}$ & $\mathrm{S}$ & $\mathrm{S}$ & $\mathrm{S}$ & $\mathrm{S}$ & $\mathrm{S}$ & $\mathrm{S}$ & $\mathrm{S}$ & $\mathrm{R}$ & $\mathrm{S}$ & $\mathrm{S}$ \\
\hline NMRIL-AA & $\mathrm{S}$ & $\mathrm{S}$ & $\mathrm{S}$ & $\mathrm{S}$ & $\mathrm{S}$ & $\mathrm{S}$ & $\mathrm{S}$ & $\mathrm{S}$ & $\mathrm{S}$ & $\mathrm{S}$ & $\mathrm{S}$ & $\mathrm{S}$ & $\mathrm{R}$ \\
\hline NMRIL-AB & $\mathrm{S}$ & $\mathrm{S}$ & $\mathrm{S}$ & $\mathrm{S}$ & $\mathrm{S}$ & $\mathrm{S}$ & $\mathrm{S}$ & $\mathrm{S}$ & $\mathrm{S}$ & $\mathrm{S}$ & $\mathrm{R}$ & $\mathrm{S}$ & $\mathrm{S}$ \\
\hline NMRIL-AC & $\mathrm{S}$ & $\mathrm{S}$ & S & $\mathrm{S}$ & $\mathrm{S}$ & $\mathrm{S}$ & $\mathrm{S}$ & $\mathrm{S}$ & $\mathrm{S}$ & $\mathrm{S}$ & $\mathrm{S}$ & $\mathrm{S}$ & $\mathrm{R}$ \\
\hline NMCA10399f & $\mathrm{S}$ & $\mathrm{S}$ & $\mathrm{S}$ & $\mathrm{S}$ & $\mathrm{S}$ & $\mathrm{S}$ & $\mathrm{S}$ & $\mathrm{S}$ & $\mathrm{S}$ & $\mathrm{S}$ & $\mathrm{S}$ & $\mathrm{S}$ & $\mathrm{S}$ \\
\hline
\end{tabular}

a PWB isolates: From most virulent isolate (PWB 99) to least virulent (PWB 101).

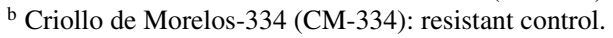

c Resistant phenotype: no lesions on roots.

${ }^{\mathrm{d}}$ From most resistant (NMRIL-F) to least resistant (NMRIL-AC).

e Susceptible phenotype: ranging from small lesions on roots to death of plants.

f NMCA 10399: susceptible control.

TABLE 3. Race designation of the 13 Phytophthora capsici isolates using the New Mexico recombinant inbred line (NMRIL) host differentials

\begin{tabular}{|c|c|c|c|c|c|c|c|c|c|c|c|c|c|}
\hline PWB designation & $24^{\mathrm{a}}$ & 66 & 80 & 85 & 86 & 90 & 91 & 94 & 97 & 98 & 99 & 101 & 103 \\
\hline Race designation & $1^{\mathrm{b}}$ & 2 & 3 & 4 & 5 & 6 & 7 & 8 & 9 & 10 & 11 & 12 & 13 \\
\hline Mating types & $\mathrm{A} 2^{\mathrm{c}}$ & A1 & A1 & $\mathrm{A} 2$ & A1 & A1 & A1 & A1 & A1 & A1 & $\mathrm{A} 2$ & A1 & $\mathrm{A} 2$ \\
\hline Host differentials & \multicolumn{13}{|c|}{ Differential reactions } \\
\hline NMRIL-A ${ }^{\mathrm{d}}$ & $\mathrm{R}^{\mathrm{e}}$ & $\mathrm{R}$ & S & $\mathrm{R}$ & $\mathrm{R}$ & $\mathrm{S}$ & $\mathrm{R}$ & $\mathrm{S}$ & $\mathrm{S}$ & $\mathrm{R}$ & S & $\mathrm{S}$ & $\mathrm{S}$ \\
\hline NMRIL-B & $S^{f}$ & $\mathrm{~S}$ & $S$ & $\mathrm{R}$ & $\mathrm{R}$ & $\mathrm{R}$ & $\mathrm{S}$ & $\mathrm{R}$ & $\mathrm{R}$ & $\mathrm{R}$ & $\mathrm{S}$ & $\mathrm{R}$ & $\mathrm{S}$ \\
\hline NMRIL-F & $\mathrm{R}$ & $\mathrm{R}$ & $\mathrm{R}$ & $\mathrm{R}$ & $\mathrm{R}$ & $\mathrm{R}$ & $\mathrm{R}$ & $\mathrm{R}$ & $\mathrm{R}$ & $\mathrm{R}$ & $\mathrm{R}$ & $\mathrm{R}$ & $\mathrm{R}$ \\
\hline NMRIL-G & $\mathrm{S}$ & $\mathrm{S}$ & S & $\mathrm{S}$ & $\mathrm{S}$ & $\mathrm{R}$ & $\mathrm{S}$ & $\mathrm{R}$ & $\mathrm{R}$ & $\mathrm{S}$ & $\mathrm{S}$ & $\mathrm{R}$ & $\mathrm{S}$ \\
\hline NMRIL-H & $\mathrm{R}$ & $\mathrm{R}$ & $\mathrm{R}$ & $\mathrm{R}$ & S & $\mathrm{R}$ & $\mathrm{R}$ & $\mathrm{S}$ & $\mathrm{R}$ & $\mathrm{R}$ & $\mathrm{S}$ & $\mathrm{R}$ & $\mathrm{R}$ \\
\hline NMRIL-N & $\mathrm{S}$ & $\mathrm{S}$ & $S$ & $\mathrm{~S}$ & S & $\mathrm{R}$ & $\mathrm{S}$ & $\mathrm{R}$ & $\mathrm{S}$ & $\mathrm{S}$ & $\mathrm{S}$ & $\mathrm{R}$ & $\mathrm{S}$ \\
\hline NMRIL-X & $\mathrm{R}$ & $\mathrm{S}$ & $\mathrm{R}$ & $\mathrm{S}$ & $\mathrm{R}$ & $\mathrm{R}$ & $\mathrm{S}$ & $\mathrm{S}$ & $\mathrm{S}$ & S & $\mathrm{S}$ & $\mathrm{S}$ & $\mathrm{R}$ \\
\hline NMRIL-Z & $\mathrm{R}$ & $\mathrm{S}$ & S & $\mathrm{S}$ & $\mathrm{R}$ & $\mathrm{R}$ & $\mathrm{S}$ & $\mathrm{R}$ & $\mathrm{R}$ & $\mathrm{R}$ & $\mathrm{S}$ & $\mathrm{R}$ & $\mathrm{R}$ \\
\hline
\end{tabular}

a PWB isolates: arranged in numerical order.

b New race designation: from race 1 to race 13 .

c Mating type determination: A1 and A2.

d Arranged in alphabetical order.

e Resistant phenotype: no lesions on roots.

f Susceptible phenotype: ranging from small lesions on roots to death of plants. 
of $P$. capsici in different regions, and how this changes over time, as has been shown with $P$. infestans and $P$. parasitica var. nicotianae $(5,15)$. The availability of resistance to different races within the gene pool of the host $(9,12)$, and improving the understanding of the inheritance of race-specific resistance $(17,18)$. Ultimately this greater understanding of the genetics of the $P$. capsici-C. annuum interaction will support breeding for effective resistance and the development of durable strategies for exploiting resistance in the field.

\section{ACKNOWLEDGMENTS}

A contribution of the New Mexico Agricultural Experiment Station, New Mexico State Univ., Las Cruces. We thank J. Prince for isolate PPc2 $(\mathrm{M})=($ PWB 103)

\section{LITERATURE CITED}

1. Ashfield, T., Danzer, J. R., Held, D., Clayton, K., Keim, P., SaghaiMaroof, M. A., Webb, D. M., and Innes, R. W. 1998. Rpg1, a soybean gene effective against races of bacterial blight, maps to a cluster of previously identified disease resistance genes. Theor. Appl. Genet. 96:1013-1021.

2. Bosland, P. W., and Lindsey, D. L. 1991. A seedling screen for Phytophthora root rot of pepper, Capsicum аппиит. Plant Dis. 75:10481050.

3. Black, W., Mastenbroek, C., Mills, W. R., and Peterson, L. C. 1953. A proposal for an international nomenclature of races of Phytophthora infestans and of genes controlling immunity in Solanum demissum derivatives. Neth. J. Plant Breed. 3:173-240.

4. Chahal, G. S., and Gosal, S. S. 2002. Principles and Procedures of Plant Breeding: Biotechnological and Conventional Approaches. Alpha Science International Ltd., Pangbourne, UK

5. Daayf, F., and Platt, H. W. 2004. Changes in race structure of Gpi 100:111:122 and Gpi 100:100:111 populations of Phytophthora infestans in Canada during 1997-1999. Can. J. Plant Pathol. 26:548-554.

6. Erwin, D. C., and Ribeiro, O. K. 1996. Phytophthora Diseases Worldwide. American Phytopathological Society Press, St. Paul, MN.

7. Fernandez, C. M. 1979. Changes in races of Phytophthora infestans (Mont.) de Bary observed in southern Chile from 1963 to 1967. Agric. Tech. Santiago 39:7-10.
8. Fernandez-Pavia, S., Biles, C. L., Waugh, M., Onsurez-Waugh, K., Rodriguez-Alvarado, G., and Lidell, C. M. 2004. Characterization of southern New Mexico Phytophthora capsici Leon. isolates from pepper (Capsicum апnиum L.). Rev. Mex. Fitopatol. 22:82-89.

9. Miller, S. A., Miller, M. L., Ivey, L., and Mera, J. 2002. Responses of pepper cultivars and experimental breeding lines to Phytophthora blight, 2001. Biological and cultural tests for control of plant disease. (Online) Rpt. 17:V16. DOI: 1094/BC17. American Phytopathological Society, St. Paul, MN.

10. Murphy, A. 2001. What are the NRBK selections? Potato Gene Resources Newsletter No. 8.

11. Oelke, L. M., Steiner, R., and Bosland, P. W. 2003. Differentiation of race specific resistance to Phytophthora root rot and foliar blight in Capsicum аппиит. J. Am. Soc. Hortic. Sci. 128:213-218.

12. Reifschneider, F. J. B., Boiteux, L. S., Della Vecchia, P. T., Poulos, J. M., and Kurdoda, N. 1992. Inheritance of adult-plant resistance to Phytophthora capsici in pepper. Euphytica 62:45-49.

13. Ristaino, J. B., and Johnston, S. A. 1999. Ecologically based approaches to management of Phytophthora blight of bell pepper. Plant Dis. 83:10801089.

14. SAS Institute, Inc. 2002-2003. Version 9.1. Cary, NC.

15. Sullivan, M. J., Melton, M. J., and Shew, T. A. 2005. Managing the race structure of Phytophthora parasitica var. nicotianae with cultivar rotation. Plant Dis. 89:1285-1294.

16. Sy, O., Steiner, R., and Bosland, P. W. 2005. Inheritance of Phytophthora stem blight resistance as compared to Phytophthora root rot and Phytophthora foliar blight resistance in Capsicum annuиm L. J. Am. Soc. Hortic. Sci. 130:75-78.

17. Tang, S., Heesacker, A., Kishore, V. K., Fernandez, A., Sadik, E. S., Cole, G., and Knapp, S. J. 2003. Genetic mapping of the $\mathrm{Or}_{5}$ gene for resistance to Orobanche race E in sunflower. Crop Sci. 43:1021-1028.

18. Tekeoglu, M., Tullu, A., Kaiser, W. T., and Muehlbauer, F. J. 2000. Inheritance and linkage of two genes that confer resistance to fusarium wilt in chickpea. Crop. Sci. 40:1247-1251.

19. Tuite, J. F. 1969. Media and nutrient solutions used by plant pathologists and mycologists. Page 73 in: Plant Pathological Methods: Fungi and Bacteria. Burgess Publishing Company, Minneapolis, MN.

20. Walker, S. J., and Bosland, P. W. 1999. Inheritance of Phytophthora root rot and foliar blight resistance in pepper. J. Am. Soc. Hortic. Sci. 124:1418 .

21. Yue, P., Arelli, P. R., and Sleper, D. A. 2001. Molecular characterization of resistance to Heterodera glycines in soybean PI 438489B. Theor. Appl. Genet. 102:921-928. 